\title{
TRANSFER OF QUASI IN REM ACTIONS UNDER 28 U.S.C. \$ 1404(a): A STUDY IN THE INTERPRETATION OF "CIVIL ACTION"
}

\section{A recent amendment to the Federal Rules of Civil Procedure allows}

quasi in rem actions to be commenced by an original writ of attachment, garnishment or a similar seizure in the federal courts. 1 While quasi in rem actions may be justified by the convenience afforded to local plaintiffs, ${ }^{2}$ they may also facilitate the assertion of claims in forums highly inconvenient to defendants. ${ }^{3}$ It seems probable that such defendants

1 FED. R. Crv. P. 4(e) (July 1, 1963): "[W] henever a statute or rule of court of the state in which the district court is held provides (I) for service of a summons, or of a notice, or of an order in lieu of summons upon a party not an inhabitant of or found within the state, or (2) for service upon or notice to him to appear and respond or defend in an action by reason of the attachment or garnishment or similar seizure of his property located within the state, service may in either case be made under the circumstances and in the manner prescribed in the statute or rule."

Although the language of 28 U.S.C. $\$ 1655$ (1958) seems to authorize original quasi in rem actions in the federal courts, $\S 1655$ has long been considered to refer only to pre-existing liens on property. B. Currie, Attachment and Garnishment in the Federal Courts, 59 Mrch. L. Rev. 337, 373-74 n.162 (1961); cf. Blume, Actions Quasi in Rem Under Section 1655, Title 28 U.S.C., 50 Mrch. L. Rev. 1, 5 (1951), arguing that $\S 1655$ is a grant of power to adjudicate in rem and quasi in rem actions. While \$ 11 of the Judiciary Act of 1789, ch. 20, I Stat. 73, and its progeny also seemed to cover quasi in rem actions, they were construed otherwise. Big Vein Coal Co. v. Read, 229 U.S. 31 (1913); Toland v. Sprague, 37 U.S. (12 Pet.) 300, 329 (1838). But see generally Currie, supra.

2 See Currie, supra note 1, at 370. "Attachment and garnishment are remedies that are necessary and proper for protection of the interests of local people having claims against non-residents . . . Id. at 380. But see Carrington, The Modern Utility of Quasi in Rem Jurisdiction, 76 HARv. L. REv. 303 (1962), arguing that the extension of the modern concept of in personam jurisdiction has eliminated the justification for quasi in rem jurisdiction. Personal jurisdiction is normally preferred to quasi in rem and is generally available in a routine diversity case whenever the defendant has certain "minimum contacts" with the forum state. Whenever the plaintiff chooses to proceed quasi in rem he has, almost by hypothesis, chosen a forum grossly inconvenient to the defendant.

3 It seems that venue for an original quasi in rem action will lie in accordance with the normal diversity requirements of 28 U.S.C. \& 1391 (Supp. IV, 1962). The Advisory Committee's notes to $\S 4(e)$ suggest this: "The necessity of satisfying . . . requirements of venue will limit the practical utilization of these methods of effecting service." 28 U.S.C.A. at 462. Professor Brainerd Currie assumes that under $4(e)$ diversity venue will have to be satisfed. Currie, supra note 1 , at 340,362 . It is clear that, by itself, rule 4(e) cannot expand statutory venue. FED. R. CIv. P. 82. Therefore, it is likely that existing statutory provisions, 28 U.S.C. § 1391 (Supp. IV, 1962), will control venue for the original quasi in rem action. One of the purposes of the federal venue provisions is to ensure convenience to the defendant by limiting the number of forums in which the plaintiff may bring suit without the defendant's consent. To permit venue to be laid wherever property belonging to the defendant 
will seek to employ the federal transfer statute 28 U.S.C. Section 1404(a). ${ }^{4}$ This comment will explore the availability of transfer of a quasi in rem action in the light of the two principal Supreme Court cases construing the relevant portions of this statute.

Section 1404(a) allows transfer of a civil action to any district "where it might have been brought," provided the statutory requirements of justice and convenience to the parties are met. In Hoffman v. Blaski,5 the Supreme Court settled a circuit conflict over the proper interpretation of "where it might have been brought." Plaintiffs, residents of Illinois, brought a patent infringement suit against a Texas corporation in Texas, the only place where jurisdiction and venue were proper. ${ }^{6}$ Defendants moved for transfer to Illinois, waiving the jurisdictional and statutory venue deficiencies. Transfer was granted and affirmed on mandamus to the Fifth Circuit. ${ }^{7}$ After transfer to the district court in Illinois, a motion by the plaintiff for retransfer was denied, but the Seventh Circuit reversed. 8 On certiorari to the Supreme Court, the sole issue was whether a transferee forum which had jurisdiction and venue only by virtue of the defendant's consent was one in which the action "might have been brought." Affirming the Seventh Circuit, the Supreme Court held that the statutory language requires an alternative forum, available when the suit was commenced in the transferor court, where the plaintiff had the power to compel the defendant to appear or suffer a default

may happen to be located would be to increase the number of potentially inconvenient forums in which the defendant might be sued. This contradicts a major purpose of the federal venue provisions.

Presently, however, a plaintiff may bring suit quasi in rem against the defendant in any state court with jurisdiction over property of the defendant. Upon removal by the defendant to the federal court, venue is proper in the district from which the case was removed, since the removal motion acts as a waiver of venue objections. See Blume, supra note 1 , at 3, and cases cited therein. Therefore, if a plaintiff seeks to bring a quasi in rem action in an inconvenient forum, he is at liberty to sue in the courts of any state in which property of the defendant is located, but he may not sue in the federal forum, except on removal. It was partly to dispel this anomaly that rule 4(e) was amended. Notes of Advisory Committee on Rules, 28 U.S.C. 4(e). To limit venue to normal diversity requirements will not serve effectively to bring federal practice in line with that of the states.

428 U.S.C. $\$ 1404$ (a) (1958) states: "For the convenience of parties and witnesses, in the interest of justice, a district court may transfer any civil action to any other district or division where it might have been brought."

5363 U.S. 335 (1960).

6 Under 28 U.S.C. $\$ 1400$ (b) (1958), venue in patent infringement actions lies only at the defendant's residence or "regular and established place of business." It was conceded that the defendant did not reside or carry on business in Illinois. 363 U.S. at $336-37,341$.

7 Ex parte Blaski, 245 F.2d 737 (5th Cir. 1957).

8 Blaski v. Hoffman, 260 F.2d 317 (7th Gir. 1958). 
judgment.9 It seemed "plain" to the Court, 10 although not to the dissenters, ${ }^{11}$ nor to nearly half the courts which had considered the problem, ${ }^{12}$ that consent to be sued could not create additional transferee forums under 1404(a).

In all cases, Hoffman severely limits the forums available for transfer under 1404(a). The decision may, in fact, preclude transfer of those quasi in rem actions which are analogous to in rem actions. Even before the Hoffman decision, it was argued that in rem actions could never be transferred because the property, whose title will be determined as "against the whole world,"13 could be located in only one place at the time the action was brought. ${ }^{14}$ However, some courts had held that the defendant's consent to move his property or to substitute a bond or stipulation for the res could create additional forums. ${ }^{15}$ This latter procedure was foreclosed by Hoffman. In rem and quasi in rem actions have in common the fact that physical power over property is the basis of the court's jurisdiction. ${ }^{16}$ To the extent that they also share the char-

9 Quoting the Seventh Circuit, the Supreme Court explained: "If when a suit is commenced, plaintiff has a right to sue in that district, independently of the wishes of the defendant, it is a district 'where [the action] might have been brought." 363 U.S. at 344 .

10 Ibid.

11 Sce dissent by Mr. Justice Frankfurter in Sullivan v. Behimer, 363 U.S. 335, 355 (1960), the companion case to Hoffman v. Blaski.

12 See id. at $355-58$, and cases cited therein.

13 Restatearent, Judgments $\$ 2$ (1942).

14 Courts construing the Federal Food, Drug and Cosmetic Act, 52 Stat. 1042 (1938), 21 U.S.C. \$ 331 (1958) apply language purportedly of general applicability to in rem actions. In United States v. 91 Packages, More or Less, Nutrilite Food Supplement, 93 F. Supp. 763, 764 (D.N.J. 1950), the court asked whether the actions before it were "such actions as might have been brought in any other districts than those in which they were brought? The answer is, no, because they were brought as actions in rem, and as such could be commenced only where the res was found at the time." In Fettig Canning Co. v. Steckler, 188 F.2d 715, 718 (7th Cir.), cert. denied, 341 U.S. 951 (1951), the court reasoned that since "the basis of all jurisdiction in rem is the court's actual or constructive possession" and since "the res must be within the reach of the court," there was no other district in which the action might have been brought. See also Clinton Foods, Inc. v. United States, 188 F.2d 289 (4th Cir.), cert. denied, 342 U.S. 825 (1951); United States v. 23 Gross Jars, More or Less, of Enca Cream, 86 F. Supp. 824 (N.D. Ohio 1949); cf. Hughes v. S.S. Santa Irene, 209 F. Supp. 440, 442 (S.D.N.Y. I962) (dictum). Since the execution of a destruction judgment is upon the seized goods themselves, however, these cases under the Pure Food, Drug and Cosmetic Act are not analogous to quasi in rem actions commenced by attachment, garnishment or similar process.

15 These cases are principally admiralty libels in rem. Typical is Torres $v$. Walsh, 221 F.2d 319 (2d Cir.), cert. denied, 350 U.S. 836 (1955), which allowed transfer because the defendant consented to appear in the transferee forum and was required to file a bond or a stipulation there.

16 REstATEMENT, JUdGMENTS, Introductory Notes 2, 3 (1942). A quasi in rem action affects only the interests of particular persons in an attached or garnished "res" against 
acteristic that specific property before the court is necessary to adjudicate the claim, Hoffman precludes transfer. Therefore, the in rem analogy is compelling in the case of quasi in rem actions brought to resolve conflicting title claims to property; ${ }^{17}$ the analogy is not persuasive however, where the quasi in rem action is commenced by attachment or garnishment in order to obtain a judgment against the defendant which will be satisfied out of the property before the court. In this instance, the nature of the property before the court is a matter of indifference to the plaintiff who is interested only in securing valuable property for the purposes of sale after judgment. Assuming that there is property located in a proposed transferee forum whose judgment sale value exceeds the value of his claim, the plaintiff has no interest in preserving the particular attachment in the transferor forum. Transfer of a quasi in rem action should not be barred when property of the defendant is available in the proposed transferee district, and the basis of the claim is, in essence, a personal claim against the defendant secured by attachment process. In this situation, it is as proper to say that two districts may simultaneously have quasi in rem jurisdiction as it is to say that two districts may have in personam jurisdiction.

If the value of the property which could be attached in the transferee court is less than the value of the claim and less than the value of the attachment in the transferor forum, the plaintiff would be denied that fairness which 1404(a) insures by allowing transfers only "in the interest of justice." The degree to which the plaintiff would be prejudiced by transfer from one district having quasi in rem jurisdiction to another in which property of the defendant is located should be a factor weighed by the trial court. The idea that only one forum can have quasi in rem jurisdiction rests on a too facile analogy to the in rem action.

The availability of transfer under Hoffman, where two districts can be said to have quasi in rem jurisdiction, does not solve all the problems of the inconvenienced defendant. Where transfer under this rationale is denied in "the interest of justice," or where funds of the defendant are not located in other than the transferor district, ${ }^{18}$ a question arises

which the plaintiff's claim is applied. $I d$. at $\S 3$; see also $i d$. at $\S \S 34-40,75$; GoodRIcH, CoNfLICT OF LAWS, 155-225 (3d ed. 1949).

17 Actions to quiet the title to land or to remove a cloud on title are examples of this. Restatement, Judgments \& 3(b) (1942). See Buchanan v. Girvin, 142 Tex. 134, 176 S.W.2d 729 (1944) (partition); Park v. Powers, 2 Cal. 2d 590, 42 P.2d 75 (1935) (quiet title); Hill v. Henry, 66 N.J. Eq. 150, 57 Atl. 554 (1904) (trespass to try title).

18 If venue for quasi in rem actions must conform to the venue provisions of 28 U.S.C. § 1391, the forums available for transfer would necessarily be limited-in the case of suit against an individual to the place of residence of either party, and in the case of suit against a corporation, to any place in which it is licensed to do or is doing business or is incorporated. Especially in the case of a corporate defendant, 
as to whether the quasi in rem action may be transferred to a district which had in personam jurisdiction over the defendant at the time suit was brought. In Hoffman, "there was no basis whatever, other than consent, for jurisdiction in the transferee forum."19 The issue left unanswered was whether judicial authority to compel the defendant to appear in the transferee court must arise out of the same exercise of jurisdictional power as in the transferor court. That issue turns on the construction of the statutory term "civil action" which was not considered by the Supreme Court until Continental Grain Co. v. Barge FBL585.20

In Continental, plaintiff grain company brought an admiralty libel in rem against a barge and an in personam libel against the barge owner for the negligent sinking of the barge, loaded with plaintiff's grain. At the time the action was brought, the barge was located in the transferor district, and a stipulation for value was entered. ${ }^{21}$ In personam jurisdiction was available in the transferee district at the time suit was commenced, but the libel in rem could not have been brought there, absent the defendant's consent, since the barge was in the transferor district at that time. ${ }^{22}$ Thus both Hoffman and traditional concepts of jurisdictional power argued against transfer. In granting the defendant's motion, the Supreme Court injected content into the statutory phrase "civil action." Hoffman was construed to bar transfer to a district "in which that 'civil action' could not have been brought because the defendant legally could not have been subjected to suit there at the time when the case was originally filed." 23 The plaintiffs in Hoffman "would have had no right whatever to proceed originally against the defendants on the 'civil actions" "24 without their consent. In Continental, however, "there was admittedly a right on the part of the grain' company to subject the

therefore, it is possible that transfer to a place where none of the defendant's funds are available may be desirable "in the interest of justice."

10 Hughes v. S.S. Santa Irene, 209 F. Supp. 440, 442 (S.D.N.Y. 1962).

20364 U.S. 19 (1960).

21364 U.S. at 29 (Whittaker, J., dissenting). A stipulation is an undertaking by the defendant for the value of the claim against the property, and "is a complete substitute for the res." J.K. Welding Co. v. Gotham Marine Corp., 47 F.2d 332, 335 (S.D.N.Y. 1931). For a general analysis of the legal effects and usages of bonds and stipulations for value, see GilMore \& BLACK, THE LAw OF AdMIRALTY, §§ 9-89 (1957), and Brief for Respondent, pp. 10-23, Continental Grain Co. v. Barge FBL-585, 364 U.S. $19(1960)$. The filing of a bond in the admiralty in rem situation would seem to transform the action into one quasi in rem. Cf. Note, 60 Colum. L. Rev. 1035, 1038-39 (1960).

22364 U.S. at 22.

23 Ibid. (Emphasis added.)

24 Ibid. (Emphasis added.) 
owner of the barge, with or without its consent, to a 'civil action' in Memphis at the time the New Orleans action was brought."25

After distinguishing Hoffman, the Court turned to consider the nature of the "civil action" in the case before it. The argument that the libel in rem could not have been brought in the transferee forum since the res was located in the transferor forum at the time suit was brought was finessed by the court. The "practical economic fact of the matter," 28 the court argued, was that the plaintiff's in rem and in personam claims actually constituted "inseparable parts of one single 'civil action'" against the barge owner. ${ }^{27}$ The libel in rem against the barge was a "long-standing admiralty fiction" 28 and "a fiction born to provide convenient forums should not be transferred into a weapon to defeat that very purpose."20 Thus it was "an alternative way of bringing the owner into court" and "the substance of what had to be done to adjudicate the rights of the parties was not different at all."30

This language suggests that a court, in construing the term "civil action," should look to the practical effects of transfer on the parties' legal relations, rather than merely to the form in which suit is brought. ${ }^{31}$ While Hoffman restricts the available forums for transfer by a narrow construction of the phrase "where it might have been brought," Continental offers a construction of "civil action" which may permit the transfer of an action "in the interest of justice," even though the defendant could not have been compelled to defend the same form of action in the transferee forum at the time suit was initiated.

Continental, then, is not as opposed to the holding and reasoning of Hoffman as at least one commentator has supposed. ${ }^{32}$ Despite this, Farns-

25 Ibid.

$28 I d$. at 26.

$27 \mathrm{Id}$. at 27.

$28 I d$. at 22.

$29 \mathrm{Id}$. at 23. The Court seemed concerned that the effect of allowing the joinder would be to "practically scuttle the forum non conveniens statute so far as admiralty actions are concerned. All a plaintiff would need to do to escape from it entirely would be to bring his action against both the owner and the ship, as was done here." Id. at 24-25.

$30 \mathrm{Id}$. at 26.

31 "The idea behind $\S 1404$ (a) is that where a 'civil action' to vindicate a wronghowever brought in a court-presents issues and requires witnesses that make one District Court more convenient than another, the trial judge can, after findings, transfer the whole action to the more convenient court." Ibid. (Emphasis added.) The approach this language suggests delves far beyond what Mr. Justice Whittaker notes in dissent to be "established principle" and "historic difference and distinction," id. at $33,37-38$, to an analysis of the substance of the action presented in each case.

32 See I Moore, Federal Practice fo 0.145 [6.-4] at 1800 (2d ed. 1961). 
worth of Chambers Co. $v$. Phinney ${ }^{33}$ is the only subsequent case which accepts the analysis here proposed. ${ }^{34}$ In that case a taxpayer brought a refund action against the District Director of Internal Revenue in the Western District of Texas, the only place where venue could be laid.95 The Director sought transfer to the Southern District of Texas, where the plaintiff might have brought suit under the Tucker Act, ${ }^{36}$ naming the United States rather than the Director as defendant. ${ }^{37}$ Using Continental's approach to the statutory phrase "civil action," the Director argued that there was no substantial distinction between a suit against the Director and a suit against the United States for the purpose of tax refunds. Denying the motion for transfer, the Fifth Circuit appeared sympathetic to the government's analysis, but felt: "compelled to recognize the distinction between actions against the United States and actions against the District Director, until Congress obliterates the distinction or the Supreme Court rules that the distinction is a fiction no longer entitled to respect." 38

Thus the court determined that the "separate 'incidents' attaching to the different causes of action" 39 were sufficient to prevent the suit against the Director and the suit under the Tucker Act from being considered a single civil action for purposes of 1404(a). The "separate incidents" that the court considered significant were that venue is different under the two suits, ${ }^{40}$ that the defendants differ, at least nominally, and that

33297 F.2d 681 (5th Cir. 1962).

34 The courts have taken differing views on the relationship between Hoffman and Continental. One court has treated Continental as sui generis: "The transfer sanctioned in Continental Grain ... is no help to respondent and intervenors, for that decision is premised on a fiction peculiar to the admiralty law." Barrack v. Van Dusen, 309 F.2d 953, 957 (3d Cir. 1962), cert. granted, 372 U.S. 964 (1963), reversing Popkin v. Eastern Air Lines, Inc., 204 F. Supp. 426 (E.D. Pa. 1962). Another approach to Continental is to allow transfer when two claims, only one of which could have been brought in the transferee district, are joined. See Hughes v. S.S. Santa Irene, 209 F. Supp. 440, 442 (S.D.N.Y. 1962); Sparks v. Graham, 196 F. Supp. 414 (N.D. Fla. 1961), which read Hoffman to require service and venue with respect to at least one defendant. But see Glicken v. Bradford, 204 F. Supp. 300, 303 (S.D.N.Y. 1962), which rejected both of these arguments. Even Farnsworth considered the two cases as treating the same general issue: "We think that the Supreme Court, in holding that a removal was warranted in the Continental Grain case did not mean to change the general rule announced two weeks previously in the Blaski case, supra." Farnsworth \& Chambers Co. v. Phinney, 297 F.2d 681, 684 (5th Cir. 1962).

35297 F.2d at 682 .

3628 U.S.C. § 1402(a)(1) (1958).

37 The plaintiff resided in the Southern District of Texas, the proper place of venue under 28 U.S.C. $\$ 1391$ (a) (1958).

38297 F.2d at 684, quoting Williams v. Patterson, 289 F.2d 485, 486 (5th Cir. 1961). 39 Id. at 685 .

40 Ibid. 
while court costs are recoverable against the United States under the Tucker Act, they are not recoverable against the Director. ${ }^{41}$ These factors, coupled with the apparent congressional desire to keep the suits separate, ${ }^{42}$ convinced the court that transfer should be denied.

It is apparent that the line of analysis suggested in Continental and adopted in Farnsworth provides a source of fxibility within the general framework of 1404(a). If it is found that substantially the same "civil action" "might have been brought" in the transferee forum, emphasis is shifted to the discretionary factors of the "interest of justice" in determining whether transfer should be allowed. The need for such an analysis seems particularly strong in the case of transfer of a quasi in rem action to a district in which the defendant could only have been sued in personam. Modern justifications of jurisdiction, thoroughly documented elsewhere, ${ }^{43}$ have emphasized significant contacts between the defendant and a forum; such contacts, in the case of quasi in rem jurisdiction, may often be minimal. The incidence of personal jurisdiction is determined, at least ideally, by considerations of convenience and basic fairness to both parties, while quasi in rem jurisdiction may be justified only for the convenience it affords local plaintiffs. ${ }^{44}$ The high burden of inconvenience on quasi in rem defendants may well be intolerable under certain conditions, and the desirability of transfer quite strong. If transfer is made to depend, as the Continental analysis suggests, upon whether a change in the form of action with its concomitant change in the parties' legal relations will have a substantial practical effect upon them, transfer will be possible in almost every case.

Transfer of a quasi in rem action to a district which had only personal jurisdiction over the defendant at the time suit was brought ${ }^{45}$ would seem to depend on the undifferentiable nature of the quasi in rem and in personam actions in the particular case before the court. The

41 Ibid.

42 "Congress has consistently resisted the suggestion that the suit against the Director be abolished." Id. at 683.

43 See, e.g., Kurland, The Supreme Court, the Due Process Clause, and the In Personam Jurisdiction of State Courts, 25 U. Chr. L. Rev. 569 (1958); Note, Develop. ments in the Law: State-Court Jurisdiction, 73 HARv. L. REv. 909 (1960).

44 See generally Carrington, The Modern Utility of Quasi in Rem Jurisdiction, supra note 2.

45 It is hardly likely that courts would allow joinder of an in personam and quasi in rem action, as was possible in admiralty in the Continental case. Quasi in rem actions are brought because the defendant cannot be reached by any other mode of service. The ready availability of attachment and garnishment under FED. R. Crv. P. 64 (1963) makes unnecessary joinder of the two forms of action. It is doubtful, therefore, whether a court would allow a plaintiff to bring suit in such fashion. It should be noted that as rule 64 applies to actions in admiralty as well as actions at law, joinder of admiralty libels in rem and in personam actions seems equally unnecessary. 
situation where a limited appearance ${ }^{46}$ is allowed should be distinguished from that in which any appearance by the defendant is considered to be 'general. ${ }^{47}$

\section{A. Where No Limited Appearance Is Allowed}

If the transferor forum does not allow a limited appearance, the action commenced quasi in rem would generally not differ sufficiently from an in personam action, which might have been brought in the transferee forum, to warrant a refusal to transfer. 48 Under Hoffman, the crucial time for determining where the action might have been brought is the commencement of the suit by the plaintiff.49 This is also the time for a determination of the nature of the civil action sought to be transferred. At the time suit is brought, the defendant has a choice between entering a general appearance and taking a default limited to the value of the attached property, ${ }^{50}$ but this default judgment would not be res judicata in a subsequent suit in personam on the same claim. ${ }^{61}$ If the value of

46 The term "limited appearance" refers to the defendant's right to defend the claim against him only to the extent of his interest in the property which has been brought before the court. Cf. Currie, supra note 1, at 379. "Special appearance" refers to the defendant's right to appear only to contest the court's personal jurisdiction over him. REsTATENENT, JUDGMENTS \& 18 (1942).

$47 \mathrm{It}$ is unclear whether federal or state law will apply to the question of whether a limited appearance is available in an action commenced quasi in rem in the federal courts. If federal law controls, the Supreme Court should formulate a uniform principle for the federal courts. Fairness to the defendant indicates that a limited appearance should be allowed. See Currie, supra note 1, at 379; RESTATEMENT, JudGMENTS § 40 (1942); Salmon Falls Mfg. Co. v. Midland Tire and Rubber Co., 285 Fed. 214 (6th Cir. 1922). The defendant would probably offer the same defense in a further proceeding in personam on the same claim, however, to which the normal rules of collateral estoppel arguably should apply. See RESTATEMENr, JudGMENTs $\S \S 70(c), 76(2)$ (c) (1942). Given this, the defendant has little to gain by the limited appearance, except that the further claim may not be prosecuted since the plaintiff could have sued initially in personam. Nevertheless, the all or nothing choice compelled by the general appearance would seem to work an undue hardship on the defendant who has been truly inconvenienced by the location of the suit. But cf. Note, The "Right" to Defend Federal Quasi-in-Rem Actions Without Submitting to the Personal Jurisdiction of the Court, 48 Iowa L. REv. 441 (1963).

48 The trend indicated by the recent amendments and the broadening of state process "would seem to render increasingly tenuous the technical 'jurisdictional' distinctions between actions in personam and those in rem." Elliott and Green, The Proposed Amendments to Rule 4, 48 Iowa L. REv. 300, 310 (1963).

49 Hoffman v. Blaski, 363 U.S. 335, 343 (1961).

50 Without jurisdiction over the person of the defendant, a court clearly cannot enter a judgment for a value greater than the value of the attached or garnished property. REsTATEMIENT, JudGMENTS § 34(f) (1942); see also Currie, supra note 1, at 348 .

51 Strand v. Halverson, 220 Iowa 1276, 264 N.W. 266 (1935) (garnishment); Saunders v. King, 69 Ohio App. 313, 37 N.E.2d 92, 93 (1941) (attachment); RestateMENT, JudGMIENTS §§ 34(h), 76(c) (1942); see Salmon Falls Mfg. Co. v. Midland Tire \& Rubber Co., 
the property is equal to or greater than the value of the plaintiff's claim, the right to take a default would be insignificant and transfer should not be barred. If the value of the property is less than the value of the plaintiff's claim, transfer will depend on the practical significance to the parties of the defendant's right to take a default judgment. It is submitted that this right has no practical significance. The defendant, appearing to move for transfer and thereby submitting himself to the general jurisdiction of the court, indicates that he is not interested in availing himself of his limited default option. Also, the plaintiff should not be heard to resist transfer to a more convenient forum on the ground that the defendant's option, in which the defendant has shown no interest, deserves protection. Therefore, where a limited appearance is not allowed, an action commenced quasi in rem should not be considered different from an in personam action which might have been brought in the transferee forum. In this situation, quasi in rem jurisdiction would simply be "an alternative method of bringing the defendant into court." 52 If the defendant appears to contest the claim against his property, he subjects himself to the general power of the court; otherwise he defaults. The compelling policies of convenient and inexpensive trials, central to 1404(a), weigh heavily in favor of transfer of this quasi in rem action to the more convenient forum, providing "the interest of justice" is satisfied.

\section{B. Where a Limited Appearance Is Allowed}

When a limited appearance is available in the transferor forum, the question of transfer of a quasi in rem action to a district which had only in personam jurisdiction at the time suit was brought turns on the materiality of the defendant's right to defend the limited claim against his property. Lacking waiver or consent to a general appearance, the

285 Fed. 214, 219 (6th Cir. 1922); Cheshire Nat. Bank v. Jaynes, 224 Mass. 14, 18, 112 N.E. 500, 502 (1916); Annot., 103 A.L.R. 839 (1936).

52 Continental Grain Co. v. Barge FBL-585, 364 U.S. 19, 26 (1960). 'The plaintiff's interest in securing valuable property of the defendant's out of which judgment is certain to be exacted in a swift and expeditious manner, does not offer an obstacle to transfer. Procedures for securing the defendant's property are readily available in state courts, and in federal courts by rule 64. Where in personam jurisdiction can be obtained, the judgment may be executed on the defendant's property in any district in the United States, and in general it would appear likely that a district with in personam jurisdiction would also contain some property of the defendant's which could be brought before the court. At any rate, delay in execution of judgment occasioned by the lack of the defendant's property in the forum district would normally not be an inconvenience of such magnitude that the possibility of transfer under $\S 1404(a)$, assuming the other standards of "the interest of justice" can be met, should be foreclosed by the trial court. If it should appear likely that the financial or personal property of the defendant will disappear or waste before execution can be made, and security of judgment is important in the case before the court, transfer may properly be denied "in the interest of justice." 
value of the judgment will not exceed the value of the res.53 When the value of the res exceeds the amount of the claim, the limited appearance serves no purpose, and transfer should not be barred. If the value of the res is less than the amount of the claim, the defendant's right to a limited appearance is certainly, in the normal instance, a right of considerable significance. But, like default, the possibility that the defendant may exercise his right is not necessarily relevant to the question of transfer. Since the defendant seeks to transfer to a forum in which personal jurisdiction was available at the time suit was brought, the court should require that he proceed in personam as a condition of transfer. The defendant is thereby made to "waive" his right to a limited appearance in the transferee forum by his motion to transfer, and this right is no longer of importance to him for purposes of 1404(a). Similarly, the plaintiff would have no interest in the defendant's right to a limited appearance, except as an element to defeat transfer. It would seem, therefore, that where the defendant seeks transfer of a quasi in rem action to a forum which had only in personam jurisdiction, and he is made liable in personam in the transferee court, the factor of the limited appearance should not defeat transfer.

\section{Disposition of the Res}

A final problem centers on the disposition of the res upon transfer. ${ }^{54}$ Two possible solutions appear: the attachment or garnishment may be either vacated or held by the transferor court.55 Under existing state

53 Restatement, Judgments $\$ 39$ (1942).

54 This problem was neither argued before nor considered by the Court in Continental. This result may be premised on the assumption that federal district courts have power of disposition through their independent admiralty jurisdiction. Nevertheless, from the silence in Continental, a hesitant argument may be made that disposition of the res is not a critical factor governing transfer.

55 While the issue has not been decided, it would appear that state law will control the disposition of the res upon transfer. Rule 4(e) of the Federal Rules of Civil Procedure is couched in terms of state law. Also, rule 64 seems to cover disposition as well as commencement of the attachment: "At the commencement of and during the course of an action, all remedies providing for seizure of person or property for the purpose of securing satisfaction of the judgement ultimately to be entered in the action are available under the circumstances and in the manner provided by the law of the state in which the district court is held." However, the interests of uniformity and the efficient administration of federal business argue for the opposite result. Moreover, since most states allow attachments on property situated outside the district in which the action is prosecuted (e.g., ILL. REv. STAT. ch. 11, $\$ 13$ (1961); FLA. STAT. ANN. $\$ 76.16(1941)$ ), the issue of vacature on transfer does not arise. Therefore, whether the plaintiff has the right to defeat vacature by refusing to consent to the defendant's bond (see Fazzano v. Martin, 94 Conn. 91, 108 Atl. 512, 513 (1919) (dictum), suggesting this is the case), or whether the transferor court has the power to vacate for this type of cause, is a matter open to statutory construction in each 
law, it may sometimes be the case that vacature is only obtainable with the plaintiff's consent. ${ }^{56}$ This fact seems to present the consent issue again, but it is a different issue from that with which Hoffman deals. Unlike the troublesome consent in Hoffman, consent to vacature in no way affects the power of the plaintiff to subject the defendant to suit on the same "civil action" in the transferee forum. It is merely an attendant consequence to the bringing of suit initially in the transferor forum. The right to determine the disposition of the res does not seem substantial enough to warrant judicial protection for the purpose of transfer. ${ }^{57}$ Generally, when the defendant is amenable to personal jurisdiction in a routine diversity case, execution of judgment on the property of the defendant within a reasonable time is to be expected.

The other solution to the problem of the disposition of the res is that the property be kept in the transferor forum and disposed of in accordance with the judgment of the transferee court. By its terms, rule 4(e) conforms procedures for attachment and garnishment in the federal courts to those in the states. ${ }^{58}$ Nevertheless, while an original writ of attachment or garnishment may only be served on property within the state in which suit is brought, this has nothing to do with whether, upon transfer, the same property may be held in the transferor court awaiting judgment in the transferee forum. The traditional objection that a forum which does not have property within its territorial jurisdiction cannot adjudicate claims to that property seems valid for state, ${ }^{59}$ but arguably inapposite for federal forums. ${ }^{60} \mathrm{~A}$ state has no sovereignty nor jurisdictional power beyond the limits of its physical territory. Federal courts, however, derive their jurisdictional power from the sovereignty of the United States, which power is, at least potentially, coextensive with national boundaries. ${ }^{61}$ Therefore, it is arguable that, upon transfer, a federal district court has power to adjudicate claims to property which has been properly attached or garnished by any other federal district

state. As the state statutes do not deal with the problem of vacature on transfer, it is arguable that the federal courts should decide the issue on their own.

56 E.g., N.Y. Crv. Prac. Act § 6222; Minn. ANN. Stat. \$§ 570.09-12 (1947).

57 See note 52 supra.

58 See note 1 supra.

59 Restatement, Judgments $\$ 34$ (b) (1942).

60 At least in a federal question case. If, however, the rule of Erie R.R. v. Tompkins, 304 U.S. 64 (1938), is based on a constitutional command that a federal diversity court is to act as another court of the state in which it sits, then considerations founded on conceptions of state territorial sovereignty may be relevant. But cf. Griffin v. McCoach, 313 U.S. 498 (1941).

61 Restateanen, Judgments $\S 5(\mathrm{~b})$ (1942). "Congress might have authorized civil process from any circuit court, to have run into any state of the Union." Toland v. Sprague, 37 U.S. (12 Pet.) 300, 328 (1838). 
court. The uniform registration of judgments in all federal district courts $^{62}$ seems to invite utilization in this fashion.

The analysis here applied to the transfer of a quasi in rem action seeks to ascertain, in a practical fashion; the significant legal consequences of a change in the form of action occasioned by transfer. The conclusion of this comment is that under most circumstances transfer of a quasi in rem action should not be barred simply by the fact that personal, and not quasi in rem jurisdiction, is available in the transferee forum. For purposes of transfer, the practical consequences of the right to default, to enter a limited appearance and to vacate the res are not substantial enough to bar a change of venue for the civil action commenced quasi in rem. This result allows the trial judge to determine, within the broad area of discretion afforded him, in which forum the litigation should most conveniently and inexpensively proceed.

6228 U.S.C. § 1963 (1958); cf. Blume, Actions Quasi in Rem under Section 1655, 28 U.S.C., 50 MiCH. L. REv. 1, 31-32 (1951). 